This change would effect an insurance of all the interests in the property in the case of ambiguity; though practically it would mean only that liability to third parties must be denied in clear language. Insurance companies would be in the same relative position they are in now. Presently justifiable lay expectations would be checked and the broader change to insurance of all the interests in the property would be properly postponed until it can be fully justified on the basis of more extensive studies into the practical context in which these rules of fire insurance law operate.

\title{
THE NONCUMULATIVE CLAUSE AND RENEWED FIDELITY BONDS-PIG IN A POKE?
}

In Columbia Hospital for Women v. U.S. Fidelity \& Guaranty Co., ${ }^{\mathrm{x}}$ defendant surety company issued a fidelity bond indemnifying the plaintiff against defalcations by certain named employees, with a maximum indemnity of $\$ 5, \infty 00$ in the case of plaintiff's bookkeeper. Renewal was effected by subsequent issuance of a Blanket Position Bond ${ }^{2}$ affording slightly broader coverage. The second bond had no definite date of termination, but was renewable on payment of annual premiums, subject to the proviso that the payment of such premiums "shall not render the amount of this bond cumulative from year to year." Four years after the original bond was issued, a rider was attached, "extending the term for three years from the renewal date" and respectively substituting the terms "periods," "premium period" and "agreed premiums" for the words "years," "premium year" and "annual premiums" wherever they occurred in the Blanket Position Bond. Three years later, plaintiff discovered that its bookkeeper had embezzled in excess of $\$ 40,000$ over a four year period, $\$ 5,498.32$ during the year before the rider went into effect, and $\$ 3,975.47, \$ I_{3}, 28 \mathrm{r} .45$ and $\$ 17,555.90$ respectively during the three years covered by the bond and rider. The insured accordingly filed a claim for $\$ 18,975.47$ on the theory that the fidelity company's liability was $\$ 5,000$ for each year of coverage. The Court of Appeals for the District of Columbia affirmed the grant of defendant's motion for summary judgment, limiting recovery to $\$ 5,000$.

No authoritative survey has ever been conducted to determine what was an important question in the principal case, what employers really think they

I I88 F. 2d 654 (App. D.C., I95ז).

2 Fidelity bonds can be made out to cover either specifically named employees, or the occupants of designated positions for the time being. The companies have fashioned many different kinds of bonds, containing various combinations of these two basic features. Among the most widely used are the Name Schedule or Fidelity Schedule bonds, covering named employees, with or without indications of position; Position Schedules, bonding the positions listed regardless of which employees occupy them or how often the personnel shifts; and Blanket Position Bonds, covering all employees of the insured employer for the same amount, regardless of position or name. Riegel and Miller, Insurance Principles and Practices 694, 698-703 (3d. ed., r947). 
"acquire" in the way of added indemnity upon renewal of fidelity bonds. ${ }^{3}$ Frequent litigation indicates that a significant number of them feel that the renewal premiums purchase "new" coverage during the renewal period up to the stated amount of the indemnity. 4 Coverage for the old period presumably has already been paid for in full and continues together with the renewal indemnity. ${ }^{5}$ Viewed in this light, an annually renewed fidelity bond would give coverage up to the face amount for each year, with a possible total liability of twice the stated amount or more, depending on the number of renewals, ${ }^{6}$ and contrary to the result in the Columbia Hospital case.

Whether or not the expectations of employer-obligees on this matter have been correctly stated, no such coverage is offered anywhere in the field of private fidelity or guaranty insurance today. ${ }^{7}$ The actual terms of fidelity bonds vary

3 Fidelity insurance has been well defined as an agreement whereby one indemnifies another "against loss arising from the want of honesty, integrity, or fidelity of employees or others holding positions of trust. . .." John Church Co. v. Aetna Indemnity Co., I3 Ga. App. $826,83 \mathrm{I}, 80 \mathrm{~S}$. E. I093, I095 (Ig09). In general, principles of insurance law govern the treatment of fidelity bonds and contracts. Ibid. See Vance, Handbook of the Law of Insurance 9r9 ( $2 \mathrm{~d}$ ed., I930). On the question of what is accomplished by the renewal of fidelity bonds, consider the following: The controlling question is "whether the renewal create[s] a new contract or not." Fellows, J., dissenting in Michigan Mortgage Investment Co., 244 Mich. 72, 75, 221 N.W. I40, I4I (I928). "The question here is, What did the [employer] buy the first year, what did he buy the second year, and what did he buy the third year?" Aetna Casualty \& Surety Co. v. State Bank, I3 F. 2d 474, 476 (E.D. Ill., I926).

Serious questions arise as to the applicability of contract law to the insurance field. Since the insured often knows little of the real nature of the insurance contract and quite as often fails to read its provisions, it has been suggested that insurance law should be considered sui generis. Schultz, The Special Nature of the Insurance Contract, $r_{5}$ Law \& Contemp. Prob. 376, 389 (I950); Kessler, Contracts of Adhesion-Some Thoughts About Freedom of Contract, 43 Col. L. Rev. 629 (I943); Vance, supra, at 689-69o.

4 United States v. American Surety Co. of New York, I72 F. 2d I35 (C.A. 2d, r949), cert. denied 337 U.S. 930 (1950); Hack v. American Surety Co. of New York, 96 F. 2d 939 (C.A. 7 th, I938); Aetna Casualty \& Surety Co. v. State Bank, I3 F. 2d 474 (E.D. Ill., I926); Maryland Casualty Co. v. First Nat'l Bank of Montgomery, 246 Fed. 892 (C.A. 5 th, I9I7); Michigan Mortgage Investment Co. v. American Employer's Ins. Co., 244 Mich. 72, 22 I N.W. I40 (I928), noted in 27 Mich. L. Rev. 442 (I929). For an excellent compilation of many cases illustrating this point, see Extent of Liability on Fidelity Bond Renewed from Year to Year, 7 A.L.R. 2 d 946 ( $(949)$.

5 Fidelity coverage is distinctive in that actual knowledge of a defalcation may not reach the insured party until several years after its occurrence. Analogies drawn to fre and life insurance, therefore, fail to illumine the issues raised in this field. Both life and fire insurance policies give protection against single, easily discoverable calamities. Premiums will not be paid after the calamity occurs. Aetna Casualty \&Surety Co. v. State Bank, I3 F. 2d 474 (E.D. Ill., I926). See Fidelity Bonds-Does It Pay to Renew Them?, 27 Mich.I. Rev. 442 (I929); Insurance-Fidelity Bonds-Renewals As Affecting the Liability of the Surety, 25 N.C.L. Rev. 34r (I947); Fidelity Bonds-Extent of Coverage-Cumulative or Non-Cumulative, 20 So. Calif. L. Rev. 226 (r947). But cf. Leonard v. Aetna Casualty \& Surety Co., 80 F. 2d 205 (C.A. $4^{\text {th, }}$ x 935 ).

6 And the changes, if any, in the face amount of the bond from year to year.

7 Some governmental agencies, however, do receive such protection. United States v. American Surety Co. of New York, I72 F. 2d I35 (C.A. 2d, 1949). The Bureau of Internal Revenue employs the device of bonding its investigators with different companies each year. In general, recovery up to the face amounts on these bonds can be had only for defalcations 
greatly and on these different provisions the courts have based their decisions as to the nature and extent of the particular coverage afforded. ${ }^{8}$ If, for example, the original bond has a definite date of termination, a renewal may be interpreted as a separate and distinct contract. ${ }^{9}$ Coverage under such an interpretation extends to the face amount of the bond for each year, but is usually limited by a "time for discovery" clause and the restriction that liability for any one period cannot be carried over to another. ${ }^{x 0}$ But in general, and especially if there is no set date for termination, the issuance and acceptance of renewal certificates or more informal tokens of renewal is considered a continuance of the coverage. ${ }^{x}$

Fidelity companies now include cumulative liability limitation clauses like those in the principal case in practically every standard bond. They thereby seek to avoid the consequences of interpretations of bonds and renewals as separate contracts. The following provisions are typical:

The liability of the Underwriter under the bond (and under the renewal instrument) shall, in no event, exceed in the aggregate the amount carried under the bond.

occurring during the particular year covered, provided that the defalcations be discovered within two years after the terminations of the bond. Thus, there is complete yearly coverage under this scheme for a period up to three years. Communication from Aetna Insurance and Casualty Co., June I8, I95I. It has been observed that adoption of this practice by private parties would be contrary to the best interests of both the surety companies and the insured. 27 Mich. L. Rev. 442 (I929).

${ }^{8}$ In so doing few courts indulge in the notion that fidelity bonds should be governed by the principles of objective contract law. (Strictissimi juris). Guaranty Co. v. Pressed Brick Co., r9I U.S. 4I6, 424 (r903). But cf. Crane, Breed \& Breed v. The City Ins. Co., 3 Fed. 558, 5606I (S.D. Ohio, I880). A court will always demand that the terms of the contract be free from "ambiguity" in conformity with generally accepted standards of insurance law. American Surety Co. v. Pauly, I70 U.S. I33, I44 (I898); Hartford Accident \& Indemnity Co. v. Swedish Methodist Ass'n, 92 F. 2d 649, 652 (C. A. 7th, I937).

9 United States v. American Surety Co., x72 F. 2d x35(C.A. 2d, x949); Aetna Casualty and Surety Co. v. State Bank, $x_{3}$ F. 2d 474, (E.D. Ill., r926), rev'd on other grounds, I9 F. 2d 969 (C.A. 7th, I927); Maryland Casualty Co. v. First Nat'l Bank, 246 Fed. 892 (C.A. 5th, I9I7); Florida Cent. \& P.R. Co. v. American Surety Co., 99 Fed. 674 (C.A. 2d, I900); Hood v. Simpson, 206 N.C. 748, I75 S.E. r93 (I934); Ladies of Modern Maccabbees v. Illinois Surety Co., I96 Mich. 27, I63 N.W. 7 (I9I7); U.S. Fidelity \& Guaranty Co. v. Williams, 96 Miss. Io, 49 So. 742 (rgog); De Jernette v. Fidelity \& Casualty Co., 98 Ky. 558, 33 S.W. 828 (r8g6).

so Standard Accident Ins. Co. v. Collingdale State Bank, 85 F. 2 d 375 (C.A. 3d, r936); Maryland Casualty Co. v. Tulsa Industrial Loan \& Investment Co., 83 F. 2 d I4 (C.A. Ioth, I936); Fidelity \& Casualty Co. v. Consolidated Nat'l Bank, 7x Fed. II6 (C.A. 3d, I895). But cf. Leonard v. Aetna Casualty \& Surety Co., 80 F. 2d 205, 207 (C.A. 4th, r935) (time for discovery limitation clause held as negativing the intent of separate contracts). A "time for discovery" clause limits recovery to those defalcations discovered within a specified period after the termination of the bond. It is now practically settled that time for discovery limitations begin to run from the termination of the final renewal period, unless specific provision to the contrary is made. Danvers Savings Bank v. Nat'l Surety, I66 Fed. 671 (C.A. rst, r9og); First Nat'l Bank v. U.S. Fidelity \& Guaranty Co., I Io Tenn. Io, 75 S.W. Io76 (rgo3). Contra: Ladies of Modern Maccabbees v. Illinois Surety Co., Ig6 Mich. 27, I63 N.W. 7 (I9I7); De Jernette v. Fidelity \& Casualty Co., $98 \mathrm{Ky} .55^{8}, 33$ S.W. 828 (I896).

Ir Farmer's Co-op. Mercantile \& Shipping Ass'n v. Nat'l Surety Co., I7 F. 2d 527 (D.C. Kan., 1927); Leonard v. Aetna Casualty \& Surety Co., 80 F. 2d 205 (C.A. 4th, I935); John Church v. Aetna Indemnity Co., I3 Ga. App. 826, 8o S.E. 1093 (rgog). 
Regardless of the number of years this bond shall continue in force and the number of premiums which shall be payable or paid, the liability of the Underwriter under this bond shall not be cumulative in amounts from year to year or from period to period.

The liability of the Underwriter being limited to the amounts scheduled, regardless of the number of years this suretyship remains in force or the number of premiums paid.

Without exception, courts dealing with noncumulative clauses have reached the result in the Columbia Hospital case, restricting the surety company's total liability for all periods covered by bonds and renewals to the face amount of the bond. ${ }^{12}$ Thus renewals do not increase total monetary liability.

This result can be fully understood only when it is remembered that fidelity bonds generally have time for discovery limitation clauses. ${ }^{.3}$ Thus, unless the time for discovery is extended, employers must be more or less diligent in discovering defalcations to take advantage of the coverage for losses incurred during any one period. Renewal forms for practically every type of fidelity bond contain such time for discovery extension provisions, usually extending the deadline to a definite period measured after the final termination of the coverage.

The sureties argue that the renewal premiums constitute consideration specifically for these extensions. They maintain that their greatest losses result from such "continuous" contracts, even though the coverage is limited to the face amount of the bond. ${ }^{4}$ They further assert that progressively increasing premiums would be essential to support "cumulative-continuous" indemnity, i.e., coverage up to the face amount for each period plus time for discovery extension provisions. But there is no record of this type of coverage being offered to private employers anywhere, for any premium.

The fidelity companies explain this on the ground that the employer-obligees are unwilling to pay the proper premiums. Nevertheless, employers have time and again sought to have the courts construe many different kinds of fidelity bonds as cumulative. ${ }^{15}$ In spite of the consistency of the holdings construing

${ }^{12}$ New York Casualty Co. v. Ford, 145 F. 2 d 599 (C.A. 5 th, r944); Hack v. American Surety Co., 96 F. 2 d 939 (C.A. 7 th, I938), cert. denied 305 U.S. 63I (1938); Brulatour v. Aetna Casualty \& Surety Co., 8o F. 2d 834 (C.A. 2d, I936); U.S. Fidelity \& Guaranty Co. v. Barber, 70 F. 2d 220 (C.A. 6th, I934); Quinlan \& Tyson, Inc. v. Nat'l Casualty Co., 3 II Ill. App. 369, 36 N.E. $2 d 470$ (I94I).

$r_{3}$ See note ro supra. It makes sense to purchase a renewal certificate instead of a new bond only if the former has such an extension of the time for discovery. One of the consequences of omitting such a clause is well illustrated in United States v. American Surety Co., I72 F. 2d 135 (C.A. 2d, 1949). Finding no cumulative liability limitation clause and no provision regarding time for discovery, the court felt free to presume that had the government taken out fresh bonds yearly, complete coverage for each year would permanently be insured, and thus inferred that renewals must achieve the same result. See also, Hartford Accident \& Indem. Co. v. Swedish Methodist Aid Ass'n, 92 F. 2d 649 (C.A. 7 th, 1937).

$x_{4}$ Columbia Hospital for Women v. U.S. Fidelity \& Guaranty Co., r88 F. 2d 654, 657 (App. D.C., I95I); communication from Aetna Insurance \& Casualty Co., June I8, r95I.

ss Columbia Hospital for Women v. U.S. Fidelity \& Guaranty Co., r88 F. 2d 654 (App. D.C., I95r). See cases cited note 4 supra. 
bonds and contracts containing cumulative or aggregate liability limitation clauses, they have often maintained that they understood they were getting separate coverage for each year even in the presence of such clauses. Employers have construed the noncumulative clause to mean that there can be no accumulation of coverage in the sense of applying unobligated amounts from one period to the next.

This construction is, of course, reasonable, and can be challenged only on the grounds that (I) the courts have decided uniformly against it, and (2) the premiums paid do not offer adequate consideration for "cumulative-continuous" coverage.

Adopting these two arguments, the Columbia Hospital court cited cases construing similar noncumulative clauses as controlling. The court was especially impressed with the fact that three such clauses ${ }^{16}$ were included in the Superseded Suretyship Rider ${ }^{17}$ which was attached to the original Blanket Position Bond. This rider cancelled, upon the issuance of that bond, the original bond and established "continuous" liability for the periods covered by both. Notice was also taken of the last rider which, by eliminating the word "annual" from the instruments, gave further support to the idea of continuous coverage.

Judge Clark vigorously dissented. Not only was the language ambiguous, in his opinion, but "the far more reasonable construction is that it simply means that the coverage on years when no loss was suffered cannot be carried over to cover losses in a subsequent year when losses were in excess of $\$ 5,000 .{ }^{\prime \prime 8} \mathrm{He}$ maintained that the ambiguity was indicated by the difficulty which the courts have had in interpreting the noncumulative clauses, but he cited no cases. In conclusion, attention was drawn to the familiar rule that "wherever ambiguity appears in a contract it must be construed most strongly against the party who drew it and in favor of the party who did not draw it."

Judge Clark's position is supported only by dicta and dissenting opinions..$^{20}$ At best, some courts have been apologetic while following the traditional inter-

${ }^{16}$ Columbia Hospital for Women v. U.S. Fidelity \& Guaranty Co., I88 F. 2d 654, 658 (App. D.C., I95r). The key words in three clauses were as follows: (r) "liability ... shall not be cumulative in amounts ..."; (2) "the liability ... shall, in no event, exceed in the aggregate the amount carried under the attached bond"; (3) "liability ... shall not be cumulative."

17 I.e., the clause explaining the extent of liability for the period covered by the old bond retained under the new bond. Such riders provide for continuing liability, extending the time for discovery. They also serve to enumerate the complicated details of coverage for the different periods occasioned by changes in the face amount of the bond, or the type of coverage. A cumulative liability limitation clause is found in every Superseded Suretyship Rider.

${ }^{18}$ Columbia Hospital for Women v. U.S. Fidelity \& Guaranty Co., x88 F. 2d 654, 66I (App. D.C., I95I).

19 Ibid.

${ }^{20}$ Dissents and expressions of unhappiness over the situation are prevelant. E.g., Fellows, J., in Michigan Mortgage Investment Co. v. American Employer's Ins. Co., 244 Mich. 72, 75, 22I N.W. 140, I4I (I929); Hack v. American Surety Co., 96 F. 2d 939, 945 (C.A. 7 th, 1938), cert. denied 305 U.S. 36 I (I938); Aetna Casualty \& Surety Co. v. State Bank, I3 F. 2 d 474 (E.D. Ill., I926), rev'd on other grounds, Ig F. 2 d 969 (C.A. $7^{\text {th }}$, I927). 
pretation, indicating rather meekly that they would appreciate legislative action requiring the insurance companies to clarify the language somewhat. ${ }^{2 x} \mathrm{Can}$ it then be maintained that the words are in any sense ambiguous?

It has been said that "there can be no ambiguity when a term has been judicially defined." ${ }_{22}$ But this blanket statement presents grave difficulty. The language of the standard noncumulative clause is by no means clear or free from doubt. ${ }^{23}$ Yet the non-expert employer-obligee, who at no time participates in its drafting, is charged with expert knowledge of the cases construing such clauses. He is also charged by the courts with expert knowledge of comparative insurance premiums and rates.

Fidelity and guaranty insurance law is supposedly governed, for present purposes, by the same principles controlling general insurance law. ${ }^{24}$ The watchword utilized by all the courts in the latter field has always been "Verba Chartarum fortius accipiuntur contra proferentem." ${ }_{25}$ The sense of this doctrine is simply that parties to insurance contracts usually deal on an unequal basis, thus tempting the insurer to word the policy so as to attract a bevy of customers, while subtly minimizing the risk of actual liability. ${ }^{25}$

2x "It is true that the practical effect of such clauses in fidelity bonds, $\ldots$ is the creation of a situation wherein one employer buying fidelity insurance each year in a new company receives multiple protection, whereas another who, because of satisfactory dealings with his insurer, renews in the same company, receives but single protection for all premium periods, though the cost to him is exactly the same. The remedy for this situation, however, lies with the fidelity companies or with the Legislatures, and not with the courts." U.S. Fidelity \& Guaranty Co. v. Barber, 7o F. 2d 220, 226 (C.A. 6th, I934); Hack v. American Surety Co., 96 F. 2 d 939, 945 (C.A. 7 th, I938); Jacksonville v. Bryan, I96 N.C. 721, 723-724, I47 S.E. I2, I3 (1929).

22 Order of United Commercial Travelers of America v. Knorr, II2 F. 2d 679, 682 (C.A. Ioth, I940). "If a written contract is stated so that it can be given a certain definite legal meaning, it is not ambiguous...." Provident Ins. Co. v. Bagby, I67 S.W. 2d 8I3, 8I4 (Tex. Civ. App., r94I).

${ }^{23}$ For the criteria applied by most courts in determining the existence of ambiguity, see Arkansas Amusement Corp. v. Kempner, 57 F. 2d 466, 472 (C.A. 4th, 1932); Osterholm v. Boston \& Montana Consol. Copper \& Silver Mining Co., 40 Mont. 508, 5 I9, I07 Pac. 499, 505 (Igro); Mutual Ben. Health \& Accident Ass'n v. Dixon, 27 Tenn. App. 3I2, 3I5, I80 S.W. 2d 426, 427 (r944); State Bank of Wilbur v. Phillips, Ir Wash. 2d 483, 488, II9 P. 2d 664, 666 (I94r).

${ }^{24}$ Aetna Casualty \& Surety Co. v. Commercial State Bank, I3 F. 2d 474, 475 (E.D. Ill., I926); U.S. Fidelity Co. v. First Nat'l Bank, 233 Ill. 475,84 N.E. 670 (Igo8); John Church v. Aetna Indemnity Co., I3 Ga. App. 826, 80 S.E. I093 (rgog). Vance, Handbook of the Law of Insurance 920 (2d ed., I930).

${ }_{25}$ The words of instruments are construed strongly against the one who drafts them. Co. Litt. *36a. "Where, in an insurance policy, a term is open to two or more constructions we are required to adopt the one more favorable to the insured." Fidelity \& Deposit Co. of Maryland v. Friedlander, IOI F. 2d I06, IO7 (C.A. 6th, I939), and cases cited therein. For a general account of the doctrine as it applies to contracts and leases, see Broom, Legal Maxims 402-4ro (Ioth ed., Kersley, I939). See Vance, op. cit. supra note 24, at 689. But cf. Frontier Mortgage Corp. v. Heft, I46 Md. I, I25 Atl. 772 (I924).

${ }^{26}$ Bourgeois v. Northwestern Nat'l Ins. Co., 86 Wis. 606, 6ro, 57 N.W. 347,348 ( 1893 ); De Lancey v. Rockingham Farmers' Mutual Fire Ins. Co., $5^{2}$ N.H. 581 ( 1873 ). See also 
As with most stereotyped doctrines, "Verba Chartarum" has been applied with marked inconsistency, but in many instances the courts have penalized insurance companies by interpreting doubtful or uncertain phrases, terms admitting of varying interpretations, in such a way as to maximize the insured's interest or claim..$^{27}$ In these cases, the issue was not whether as a result of judicial precedent, the language was clear to the court. The only relevant question was the clarity of meaning to the "reasonable," non-expert layman..$^{28}$

Insurance law, however, has not had a steady development. Woodruff's rhetorical question, "What do they know of the law of insurance who only the law of contract know?," ${ }_{29}$ is in much closer accord with the facts than Justice Crane's formula that "a contract for insurance is no different than any other contract.". 30

Marine insurance contracts, for example, are still incomprehensible collations of misleading jargon to the average layman, despite their standardization. ${ }^{3 \mathrm{x}}$ Judicial construction and interpretation of marine insurance contracts admits of little, if any, variation..$^{32}$ These contracts, however, are almost always negotiated by experts representing both parties. ${ }^{33}$ The courts therefore indulge in a presumption of expertise which creates allowances for otherwise misleading clauses, but which certainly should not be extended to all other kinds of insurance contracts. ${ }^{34}$

Fire insurance contract forms are also largely standardized. ${ }^{35}$ Early fire insurance practice, in some respects, was recognized by the courts to be quite vicious. Special attention was probably paid to the fact that most fire insurance customers were property-owning laymen, with no expert knowledge of either

Reilly v. Linden, $x_{5}$ I Minn. I, I86 N.W. I2I (I92r), and Patterson v. Adar, Ixg Minn. $308, \mathrm{r}_{3} 8$ N.W. $28 \mathrm{I}$ (I9I2) for developments in liberalizing the construction of liability insurance contracts.

${ }^{27}$ E.g., Aschenbrenner v. U.S.F. \& G. Co., 292 U.S. 80, 85 (r934); New York Life Ins. Co. v. Hiatt, I4O F. 2 d 752 (C.A. 9th, I944); cases cited note 23 supra. See Williams v. Union Central Co., 29 I U.S. $x 70,180$ (I934).

${ }^{28}$ Gaunt v. John Hancock Mutual Life Ins. Co., 160 F. 2d 599, 60I (C.A. 2d, I947); New York Life Ins. Co. v. Hiatt, I40 F. 2d 752, 753 (C.A. 9th, I944).

29 Woodruff, Selection of Cases on the Law of Insurance 5 (2d ed., 1924). See Satz v. Massachusetts Bonding \& Ins. Co., 243 N.Y. 385, 393, I53 N.E. 844, 846 (I926).

${ }^{30}$ Drilling v. New York Life Ins. Co., 234 N.Y. 234, 24I, I37 N.E. $3^{14}, 3^{\text {I6 }}$ (1922).

${ }^{3}$ Vance, op. cit. supra note 24, at I8-20, 40-4I. See Brough v. Whitmore, 4 T.R. 206 (I79r). See Arnould, Marine Insurance $\$$ ro (IIth ed., I924), for a copy of the standard form of marine insurance policy employed by Lloyds of London.

${ }_{32}$ Vance, op. cit. supra note 24 at $40-4 \mathrm{I}$. Cf. Marten v. Vestey Bros., Ltd., [I920] A.C. 307, I22 L.T.R. 785 ; Le Cheminant v. Pearson, 4 Taunt. 367 (18I2).

33 Patterson, Essentials of Insurance Law 239 (I935).

34 Ibid.

35 Vance, op. cit. supra note 24, at 4I-43; Patterson, op. cit. supra note 34 , at 20-22; Standard Fire Policy, Ill. Stat. Ann. (Smith-Hurd, 1950), c. 73, § 1009. 
the insurance business or the law..$^{6}$ The most serious pitfalls were avoided by liberal application of the "Verba Chartarum" doctrine, but others remained. ${ }^{37}$ The codes embodying the standard forms were developed with reference to the early cases construing the terms of fire insurance policies. ${ }^{38}$ Thus, in general, fire insurance policy terms are still construed in favor of the insured.39

It might be argued that whether separable or continuous liability of a fidelity bond insurer is more advantageous to an employer would depend upon the circumstances of the loss. Thus, if the principles used in fire insurance standardization were applied to fidelity bonds, the same bond and its renewal would be construed as separate in one case and continuous in another. $4^{\circ}$ Undoubtedly, the rules of construction defining separable and continuing contracts were intended to avoid this result.

The presence of the noncumulative clause in the Columbia Hospital case could easily have been understood as providing for separate and continuous coverage. "Cumulative" meant something entirely different to each of the contracting parties. Neither interpretation was patently unreasonable. It would seem, then, that to be consistent with the oft-stated judicial attitude towards insurance contracts generally, ${ }^{4 \pi}$ the clause should have been construed in the manner indicated by the plaintiff.

The court in this case, of course, denied that the language was ambiguous. But, sensing the necessity for further justifying the holding, it concluded with the following most extraordinary statement: "Perhaps such litigation as the instant case will serve as admonition to purchasers of insurance to read their contracts carefully and to seek expert advice with regard to the scope of the coverage." 42 (Emphasis added.)

${ }^{36}$ Patterson, Insurance Commissioner in the United States 245 ff. (r927). See also De Lancey v. Rockingham Farmers' Mutual Fire Ins. Co., 52 N.H. 581 (I873).

${ }^{37}$ E.g., breaches by the insured of conditions not material to the loss may suffice to exonerate the insurer from all obligations. Imperial Fire Ins. Co. v. Coos County, I5I U.S. $45^{2}$ (I894).

${ }^{38}$ Chauvin v. Superior Fire Ins. Co., 283 Pa. 397, I29 Atl. 326 (I925); John Davis \& Co. v. Ins. Co. of North America, II 5 Mich. 382, 73 N.W. 393 (I897). Vance, op. cit. supra note 24, at $689-693$.

39 Vance, op. cit. supra note 24, at $69 x$.

${ }^{40}$ E.g., Florida Cent. \& P. R.R. Co. v. American Surety Co., 99 Fed. 674 (C.A. 2d, r900); Proctor Coal Co. v. U.S. Fidelity \& Guaranty Co., I24 Fed. 424 (N.D. Ga., Ig03), wherein the plaintifis sought a construction of continuous coverage.

4I Insurance is "the classic example" of a "contract of adhesion," i.e., a contract not arrived at by mutual negotiation and drafting. See Thompson v. Phoenix Ins. Co., ${ }_{3} 6$ U.S. 287, 297 (189o); Schultz, Special Nature of the Insurance Contract, 15 Law \& Contemp. Prob. 376, 379 ( 1950 ); Patterson, The Delivery of a Life-Insurance Policy, 33 Harv. L. Rev. Ig8, 222 (I9r9). Vance pointed out that even businessmen rarely read their insurance policies. Vance, op. cit. supra note 24 , at 2 I5.

${ }_{42}$ Columbia Hospital for Women v. U.S. Fidelity \& Guaranty Co., I88 F. 2d 654, 659 (App. D.C., I95I). The court further refused to order a return of any of the later premiums. This had been done in a few cases on the grounds that the premiums were paid under the misapprehen- 
With few exceptions, such as the marine insurance cases, this advice is practically unprecedented in insurance law. Yet it cannot be said to represent a shift in judicial sentiment, in view of several very recent cases re-affirming the more traditional doctrine favoring the insured. ${ }^{33}$ The classical opinion still is that the primary responsibility is on the insurer to spell out as clearly as he can the terms of the indemnity. It must be noted, however, that while lip service is paid to this doctrine, real progress along these lines has always been slow and tortuous. 44

Assuming that employers are to some extent misled into believing that they receive cumulative-continuous coverage, there is good reason to ask why the fidelity companies do not attempt to clarify their language. Such a task would not be difficult. It would reduce litigation, misunderstanding and ill will. The changes thus far made in these clauses, while helpful, are inadequate. ${ }^{45}$ Since most companies act in good faith, with no desire to "trap" inexpert customers, there is no obvious reason why a comprehensive effort should not be made. However, several important considerations should be noted.

The surety companies are limited in their freedom to modify their contract forms by a supervening voluntary organization, the Surety Association of America. A committee of this Association standardizes the bonds and contracts as much as possible; substantial changes in the forms used by member companies must be ratified by the committee. $4^{6}$ Although the workings of the Association are somewhat esoteric, a certain amount of inertia in obtaining results from concerted group action of this type can be understood and appreciated. There can be no doubt, however, that the companies are aware of the problem. Perhaps

sion that they were "acquiring" new coverage. Hack v. American Surety Co., 96 F. 2d 939 (C.A. 7 th, 1938), cert. denied 305 U.S. 63I (I938). The analogy to the contract notion of rescission here is quite strong, but was in effect denied by the court's finding that there was no "ambiguity" in the terms of the bond sufficient to support a rescission. Columbia Hospital for Women v. U.S. Fidelity \& Guaranty Co., I88 F. 2 d 654, 657 (App. D.C., I95 I).

It has been suggested further that insurance should be regarded as "affected with a public interest." Kessler, Contracts of Adhesion-Some Thoughts About Freedom of Contract, 43 Col. L. Rev. 629, 635 (I943). See also Orient Ins. Co. v. Daggs, I72 U.S. 557 (I899); Citizens' Ins. Co. v. Clay, I97 Fed. 435 (E.D. Ky., I9I2), aff'd 235 U.S. 7 II (I9I3).

43 Gaunt v. John Hancock Mutual Life Ins. Co., I6o F. 2d 599 (C.A. 2d, r947); New York Life Ins. Co. v. Hiatt, I40 F. 2d 752 (C.A. 9th, I944); Kellogg v. Iowa State Traveling Men's Ass'n, 239 Iowa 196, 29 N.W. 559 (1947).

${ }_{44}$ E.g., the first standard fire insurance policy form was adopted in Massachusetts in 1873 . Mass. Stat. (I860) c. 33I (2 Supp., I873). Pronouncements of unconstitutionality, incessant revisions and much wrangling prevented final adoption of such forms in many states for another fifty years. Today many are still dissatisfied. Consult Vance, op. cit. supra note 24 , at $4 x-43$.

45 The court in the Columbia Hospital case noted the addition of the words "from year to year" in the cumulative liability limitation clause as a "concession to the need for specificity." Columbia Hospital v. U.S. Fidelity \& Guaranty Co., I88 F. 2d 654, 657 (App. D.C., I95I). But, considering the claims of the plaintiff in this case, the addition of these words appears more to contribute to the confusion, than to constitute an improvement.

${ }_{46}^{6}$ Communication from Aetna Insurance \& Casualty Co., June r8, I95r. 
the continually favorable results of litigation on the point have eased what otherwise would be incentive to change.

Possible mistrust in the good faith of the complainants in pressing their claims poses a more plausible reason for this inertia. Strong suspicions understandably arise in the minds of the sureties when, after incessant clamoring for lower rates and premiums, employers, upon loss, seek to establish coverage which would be justified only by much larger premiums. Such a view, however, loses much of its force when it is realized that, by and large, the employers have no notion as to what is a proper premium rate.

The inertia of the companies in this matter, as in most fields of insurance, is then hard to justify or explain. Although it is absurd to charge most of the companies with bad faith, it is apparent that the only satisfactory solution is for the courts consistently to apply the "Verba Chartarum" doctrine here, and to find clauses ambiguous, in spite of prior constructions to the contrary.

By the insurance companies' own admission, the courts' tendency to find ambiguities in insurance and fidelity contracts raises the level of the contingent reserves which must be kept frozen to meet unanticipated claims. ${ }^{47}$ It is submitted that the continued use of such language as that found in the typical noncumulative clause, court interpretation to the contrary, is deserving of such cold treatment.

47 Schultz, op. cit. supra note $4 \mathrm{r}$, at 390 . 